\title{
BRPKM
}

Buletin Riset Psikologi dan Kesehatan Mental

http://e-journal.unair.ac.id/index.php/BRPKM

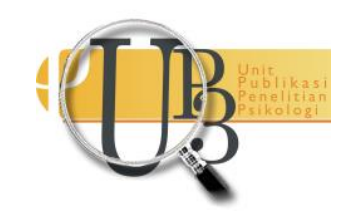

ARTIKEL PENELITIAN

\section{Psychological Wellbeing Penggemar K-Pop Dewasa Awal yang Melakukan Celebrity Worship}

MAULIDDITA SALSABILA AZZAHRA \& ATIKA DIAN ARIANA*

Departemen Psikologi Psikologi Klinis dan Kesehatan Mental, Fakultas Psikologi Universitas Airlangga

\begin{abstract}
ABSTRAK
Semakin besarnya fenomena apresiasi terhadap selebriti K-Pop tidak diimbangi dengan ketersediaan penelitian psikologi positif yang cukup dalam memahami fenomena tersebut. Penelitian ini bertujuan untuk mengetahui apakah terdapat hubungan antara celebrity worship dan psychological wellbeing pada penggemar K-Pop dewasa awal. Subjek dalam penelitian terdiri dari 1200 orang penggemar K-Pop yang merupakan individu dewasa awal berusia 18-25 tahun. Hasil analisis data menunjukkan bahwa terdapat hubungan positif yang signifikan antara celebrity worship dengan psychological wellbeing $(r=0,34$; $p=0,00$ ). Artinya, jika celebrity worship meningkat maka psychological wellbeing juga akan meningkat dan begitu pula sebaliknya.
\end{abstract}

Kata kunci: celebrity worship, dewasa awal, penggemar K-Pop, psychological wellbeing

\section{ABSTRACT}

The increasing phenomenon of appreciation towards K-Pop celebrities is not matched by the availability of sufficient positive psychological research in understanding this phenomenon. This study aims to determine whether there is a correlation between psychological wellbeing and celebrity worship among Emerging Adult K-Pop Fans. The subjects in this study were 1200 emerging adult K-Pop fans around 1825 years old. The results of data analysis showing that there is a positive correlation between celebrity worship and psychological wellbeing $(r=0,34 ; p=0,00)$. This means that if celebrity worship increases, psychological wellbeing will also increase and vice versa.

Keywords: celebrity worship, emerging adults, K-Pop fans, psychological wellbeing

Buletin Penelitian Psikologi dan Kesehatan Mental (BRPKM), 2021, Vol. 1(1), 137-148

*Alamat korespondensi: Fakultas Psikologi Universitas Airlangga, Kampus B Universitas Airlangga Jalan Airlangga 4-6 Surabaya 60286. Surel: atika.ariana@psikologi.unair.ac.id Naskah ini merupakan naskah dengan akses terbuka dibawah ketentuan the Creative Common Attribution License (CC-BY-4.0) (http://creativecommons.org/licenses/by/4.0), sehingga penggunaan, distribusi, reproduksi dalam media apapun atas artikel ini tidak dibatasi, selama sumber aslinya disitir dengan baik. 


\section{PEN D A H U L U A N}

Budaya musik populer Korea, atau yang lebih dikenal dengan istilah 'K-pop' telah menjadi fenomena yang mampu menarik banyak penggemar atau yang juga biasa disebut dengan 'fans' atau penggemar dari seluruh dunia termasuk Indonesia. Kementerian Kebudayaan, Olahraga, dan Pariwisita Korea Selatan (2011) mendefinisikan K-pop sebagai musik pop Korea yang dinyanyikan dan ditampilkan oleh artis Korea dan telah diterima secara positif oleh penggemar internasional. Menurut Chao dan Joo-Yeun (2013) terdapat 4 kategori motivasi terhadap penerimaan K-pop, yakni adanya karisma yang dimiliki oleh selebriti K-pop, motivasi untuk melakukan relaksasi mental, adanya 'the Liking Principle' yakni dimana individu akan lebih mudah untuk menyetujui sesuatu karena menyukainya, serta kedekatan budaya secara umum. Selanjutnya, Cahyani dan Purnamasari (2019) juga menjelaskan bahwa cinta para penggemar terhadap musik K-pop didasari oleh kemampuan musik para selebriti Korea yang baik, kemudian penampilan fisik juga menjadi salah satu alasan penggemar mengagumi dan mengidolakan mereka.

Fenomena K-pop merupakan salah satu bagian dari Gelombang Korea. Chang dan Park (2012) dalam Necula (2017) menjelaskan bahwa Gelombang Korea (Korean wave atau Hallyu) merujuk pada musik (K-pop), drama (K-drama), film, fashion, dan kuliner yang telah menyebar ke seluruh dunia sejak akhir tahun 1990an. Chang dan Park (2012, dalam Necula, 2017) juga menjelaskan alasan utama mengapa Gelombang Korea dapat populer di seluruh dunia adalah karena kreator dan pengguna dapat berbagi kreasi dan respon dengan mudah di area virtual atau ruang maya melalui internet, sehingga internet memiliki peranan penting dalam menghubungkan penggemar dan Gelombang Korea termasuk artis atau selebriti K-pop.

Salah satu contoh area virtual yang sering digunakan oleh para penggemar K-Pop dalam 10 tahun terakhir adalah media sosial Twitter (Kim, 2020). Penggemar K-Pop dilaporkan menggunakan Twitter untuk mendapatkan informasi terbaru dari artis atau selebriti kesukaannya, terhubung dengan penggemar lainnya, serta mengekspresikan apresiasi mereka terhadap budaya Gelombang Korea yang telah mendunia (Kim, 2020). Pada tanggal 21 September 2020, Twitter juga merilis laporan statistik Twitter K-Pop yang mengolah data antara 1 Juli 2019 hingga 30 Juni 2020. Berdasarkan laporan tersebut, ditemukan bahwa terdapat total 6,1 miliar tweet atau cuitan terkait K-Pop dalam satu tahun terakhir dari seluruh dunia (Kim, 2020). Data selanjutnya terkait Indonesia melalui laporan Twitter (Kim, 2020), negara Indonesia berada di urutan ke-4 untuk pengguna terbanyak dan urutan ke-3 untuk volume cuitan terbanyak dari seluruh dunia (Kim, 2020) dalam percakapan yang berhubungan dengan K-Pop.

Fenomena K-pop sendiri mulai memasuki pasar Indonesia di tahun 2009-2010. Pada tahun 2010 grup idola Shinee pertama kali datang ke Indonesia untuk konser tunggalnya dan mampu menjual 2.500 tiket dari 15.000 permintaan (Anwar, 2018), dan kemudian sejak itu setiap tahunnya banyak dari penyanyi Korea menggelar acara musik baik tunggal maupun kolaborasi di Indonesia. Sepanjang tahun 2019 terdapat total 44 acara K-pop yang diumumkan digelar di Indonesia, walaupun beberapa diantaranya dibatalkan karena beberapa situasi yang tidak memungkinkan.

Mandas dan kawan-kawan (2018) menyatakan walaupun budaya apresiasi terhadap selebriti barat telah jauh lebih lama masuk ke Indonesia, penerimaan terhadap budaya apresiasi terhadap selebriti dari Korea Selatan dapat sangat cepat masuk dan berkembang menjadi sangat besar karena terdapat banyak

Buletin Riset Psikologi dan Kesehatan Mental (BRPKM) 2021, Vol. 1(1), 137-148 
nilai-nilai kebudayaan yang hampir sama dengan nilai kebudayaan yang ada di Indonesia, misalnya menghormati orang yang lebih tua dan cara berpakaian, sedangkan terdapat beberapa dari unsur budaya barat yang tidak bisa di terima di Indonesia karena cenderung dinilai terlalu bebas. Berdasarkan hal tersebut akhirnya membuat apresiasi terhadap selebriti K-pop juga lebih mudah diterima karena adanya kesamaan latar belakang budaya timur, sehingga para penggemar merasa lebih terhubung karena adanya kesamaan tersebut.

Penelitian menemukan bahwa sebagian besar dari penggemar K-pop ini merupakan remaja di sekolah menengah serta mahasiswa (Puspitasari \& Hermawan, 2013). Namun, Cahyani dan Purnamasari (2019) menyatakan bahwa pada realitanya masih banyak individu dewasa awal yang masih melakukan pemujaan terhadap selebriti tertentu yang diidolakan dan bahkan menjadikan mereka sebagai seorang panutan dalam berbagai hal. Berdasarkan temuan penelitian lainnya, disebutkan bahwa 75\% dari individu usia dewasa awal memiliki ketertarikan yang kuat terhadap selebriti dalam kehidupannya, kebanyakan terhadap idola pop, bintang film, dan banyak figur lainnya (Boon \& Lomore, 2001 dalam Rosida, 2019). Hal tersebut tidak sesuai dengan teori dasar untuk memahami fenomena ini yang menjelaskan bahwa seharusnya intensitas dari pemujaan terhadap selebriti yang memuncak di masa remaja akan mulai menurun di masa dewasa (Mccutcheon dkk., 2002) karena individu dewasa awal sudah mempertajam identitasnya, mencapai autonomy atau kemandirian, dan telah merubah minat serta tujuan hidup mereka (Shofa, 2017)

Banyaknya individu dewasa awal yang masih melakukan perilaku pemujaan terhadap selebriti disebutkan oleh Rosida (2019) memiliki keterkaitan dengan tahap perkembangannya. Dalam hal ini, Santrock (2013) menjelaskan bahwa bagi sebagian besar orang tahapan menjadi seorang individu dewasa melibatkan periode transisi besar yang dimana transisi tersebut adalah dari masa remaja menuju dewasa yang merujuk dengan tumbuh dewasa dan disebut dengan masa dewasa awal. Masa dewasa awal tersebut berkisar kurang lebih pada usia 18 hingga 25 tahun (Arnett, 2012 dalam Santrock, 2013). Tahap perkembangan psikososial Erikson menjelaskan bahwa individu dewasa awal berada pada tahap intimacy vs isolation (Poole \& Snarey, 2011 dalam Rosida, 2019). Intimasi sendiri merupakan sebuah proses untuk menemukan diri sekaligus peleburan diri sendiri di dalam diri orang lain, keintiman juga membutuhkan komitmen dengan orang lain (Santrock, 2011 dalam Rosida, 2019), dan hal tersebut merupakan isu utama pada dewasa awal. Gambaran psikologis individu yang masih melakukan pemujaan selebriti pada usia dewasa awal berdasarkan Shofa (2017) dikarenakan adanya isolasi sebagai akibat dari kegagalan dalam pemenuhan intimasi.

Fenomena perilaku pemujaan terhadap selebriti pada dasarnya dapat dipahami sebagai bentuk dari interaksi parasosial yang merupakan fenomena abnormal dimana seseorang berasumsi bahwa identitas utuh dirinya menjadi terobsesi secara virtual dengan satu atau lebih selebriti (Maltby dkk., 2003). Hal tersebut mirip dengan tipe erotomanik dari gangguan delusional yang didefinisikan sebagai keyakinan delusional bahwa orang lain sangat mencintai dirinya (APA, 1994 dalam Maltby dkk, 2003), dan tipe perilaku yang mirip dengan tipe eretomanik ini dikenal sebagai celebrity worship. Dalam konteks ini, Maltby dan kawan-kawan (2006) mendefinsikan celebrity worship sebagai perilaku obsesi seseorang kepada satu atau lebih selebriti.

Hollander (2010, dalam Brooks, 2018) menjelaskan bahwa motivasi seseorang untuk melakukan perilaku celebrity worship adalah untuk mengidentifikasi dirinya dengan seseorang yang memiliki atribut identitas yang tidak ada atau kurang dalam kehidupannya seperti kekhawatiran dengan status 
sosialnya, ketidakyakinan tentang kualitas apa dalam dirinya yang layak untuk dikagumi oleh orang lain, dan isolasi sosial yang menyebabkan keinginan untuk menemukan arti hidup yang dapat terwakilkan dari kehidupan orang lain. Wann (1995, dalam Brooks, 2018) juga menyebutkan bahwa celebrity worship secara khusus dimotivasi akan kebutuhan dari stimulasi, self-esteem, pelarian, hiburan, estetika, dan afiliasi kelompok. Selanjutnya, Redmon (2016, dalam Brooks, 2018) menyebutkan bahwa ketertarikan, empati, kerinduan, dan peniruan sebagai faktor yang diasosiasikan dengan perasaan terhubung dengan selebriti tertentu.

Individu yang melakukan pemujaan terhadap selebriti mendemonstrasikan beberapa aspek patologis, termasuk memiliki fungsi psikologis dan wellbeing atau kesejahteraan yang buruk (Maltby dkk., 2001) dan biasanya mereka melakukan aktivitas pemujaannya sendirian (dan biasanya kesepian dalam aktivitas lainnya) (Rubin, dkk., 1985 dalam Maltby dkk., 2001). Maltby dan kawan-kawan, (2001) menyebutkan bahwa perilaku celebrity worship ini dapat bersifat detrimental atau akan berdampak untuk merusak seorang individu.

Perilaku celebrity worship menurut McCutcheon dan kawan-kawan (2002) terdiri dari tiga dimensi tahapan berbeda yang berkembang pada satu model kontinum psychological absorption dan addiction: tahap pertama yakni Entertainment/Social, individu mulai menyerap dengan mencari dan bertukar informasi bersama penggemar lainnya terkait selebriti favorit mereka; kemudian pada tahap penyerapan dengan kapasitas yang lebih tinggi pada tahap kedua yakni Intense Personal Feelings, individu menjadi lebih intim terlibat dan terkoneksi dengan aspek kehidupan selebriti favoritnya; lalu tahapan terkahir yakni Borderline Pathology dimana terdapat peningkatan yang lebih jauh pada kapasitas dan kebutuhan dari batas ambang penyerapan tersebut yang nantinya dapat mengarah pada individu yang terlalu mengidentifikasikan dirinya dengan selebriti favoritnya hingga menjadi sangat obsesional terhadap kehidupan selebriti mereka.

Model psychological absorption dan addiction tersebut menjelaskan perilaku celebrity worship berprogres dalam hierarki tahapan dimensi karena mengembangkan toleransi di tahapan menengah dari perilaku celebrity worship dan butuh untuk mencapai tahapan yang lebih dalam, tingkatan yang lebih patologis demi memuaskan adiksi mereka. Namun hal tersebut berlangsung secara bertahap dan hanya terjadi pada beberapa penggemar saja, dimana sebagian lainnya akan tetap pada tingkatan yang lebih rendah dan penggemar yang telah mencapai tahapan lebih tinggi juga dapat kembali pada tahapan yang lebih rendah. Sebagaimana yang sebelumnya telah disinggung, bahwa perilaku celebrity worship dapat dilakukan tanpa harus menjadi sangat obsesional yang juga berhubungan dengan status kesehatan mental.

Maltby dan kawan-kawan (2001) memberikan penjelasan lebih lanjut bahwa sebetulnya celebrity worship juga secara potensial dapat bermanfaat bagi seorang individu. Perilaku celebrity worship dapat memberikan kesempatan bagi individu untuk berpartisipasi dalam jaringan sosial sebagai penggemar melalui internet, dapat mempromosikan hubungan sosial yang produktif, serta menyediakan penyangga psikologis untuk menghadapai stresor sehari-hari. Berdasarkan logika tersebut, Maltby dan kawankawan (2001) menyampaikan bahwa aktivitas menyukai selebriti ini juga dapat bermanfaat bagi kesehatan mental dengan catatan intensitas dalam perilaku tersebut tidak dilakukan secara obsesif atau berlebihan. 
Sampai saat ini, penelitian-penelitian sebelumnya terkait celebrity worship baru sejauh membuktikan apakah terdapat hubungan kondisi kesehatan mental yang buruk dari adanya gangguan mental dengan perilaku pemujaannya terhadap selebriti kesukaannya tersebut. Dengan kata lain, ketika seorang individu memiliki gangguan maka ia akan digambarkan memiliki kondisi kesejahteraan psikologisnya yang buruk pula (Vázquez dkk., 2009). Hal ini dapat berkaitan dengan tren lama penelitian kesehatan mental yang lebih menitikberatkan pada sisi disfungsi psikologis saja, dimana sehat hanya disamakan dengan ketidakadaan penyakit daripada kehadiran dari kesejahteraan (Fava, 2012). Meskipun demikian, dengan berkembanganya psikologi positif, perhatian tradisional pada pendekatan terhadap gejala dan penyakit tersebut secara bertahap mulai memandang konsep kesehatan dengan semakin luas yang mencakup aspek kinerja optimal individu dan tidak hanya tentang ketidakadaannya penyakit (Vázquez dkk., 2009).

Konsep kesehatan mental terkait erat dengan kondisi kesejahteraan psikologis atau psychological wellbeing (disingkat PWB), yang dapat dijelaskan secara utuh melalui sebuah model teori komprehensif yang dikembangkan oleh C. Ryff dengan mengintegrasikan berbagai sudut pandang dalam menjelaskan aspek positif dari kondisi psikologis seseorang (Fava, 2012). Ryff juga mengatakan bahwa kondisi kesejahteraan optimal yang seimbang dapat berbeda dari satu orang ke orang lainnya, dimana untuk menilai kondisi kesejahteraan tidak boleh hanya dengan satu cara pandang secara langsung saja karena setiap orang memiliki kombinasi kekuatan dan kerentanannya masing-masing dimana mereka harus bekerja dengan apa yang tersedia (Fava, 2012).

Perkembangan fenomena apresiasi terhadap selebriti K-Pop yang kian membesar setiap tahunnya tidak diimbangi dengan penelitian yang menggali aspek psychological wellbeing secara utuh terkait hubungannya terhadap perilaku celebrity worship, sehingga pendekatan melalui psikologis positif juga perlu dipertimbangkan untuk melihat fenomena ini. Melalui hal tersebut, kita bisa mendapatkan penjelasan psikologis yang lebih luas dari sisi lain dibandingkan hanya sekedar melihat kondisi kesehatan mental buruk dari adanya gejala dan gangguan yang dimiliki oleh para penggemar selebriti yang melakukan pemujaan terhadap selebriti.

PWB sendiri dikonseptualisasikan sebagai sebuah kombinasi dari keadaan afek positif seperti kebahagiaan (perspektif hedonis) dan mampu berfungsi optimal serta efektif secara individual maupun kehidupan sosial (perspektif eudaimonik) (Deci \& Ryan, 2008 dalam Winefield dkk., 2012). Selanjutnya, Ryff (2013) yang mengembangkan model psikometri dari konsep PWB sejak awal 1980an menjelaskan bahwa PWB merupakan konvergensi dari beberapa kerangka fungsi-fungsi positif yang disajikan dengan pondasi teoritis untuk menghasilkan model multidimensional dari kesejahteraan. Dalam konvergensi kerangka tersebut, dimensi-dimensi yang ada mencakup luasnya area kesehatan meliputi evaluasi positif akan diri serta kehidupan masa lalunya (self-acceptance), rasa untuk melanjutkan pertumbuhan dan perkembangan sebagai seorang individu (personal growth), keyakinan akan tujuan hidup yang berarti (purpose in life), kepemilikan akan hubungan yang berkualitas dengan orang lain (positif relations with others), kapasitas individu untuk mengatur secara efektif hidup serta lingkungan mereka (environmental mastery), dan rasa untuk menentukan nasib diri sendiri (autonomy) (Ryff, 2013)

Perbedaan dampak dari perilaku celebrity worship ini mendorong penelitian lebih lanjut mengingat perkembangannya yang kian membesar seiring berkembangnya pula fenomena pemujaan terhadap selebriti K-pop. Dengan begitu, diharapkan pengetahuan terkait faktor resiko maupun protektif dapat 
dikonfirmasi sehingga dampak negatif yang mungkin ditimbulkan dapat dikontrol sekaligus mengembangkan aspek positif yang diharapkan dari perilaku celebrity worship.

Paparan sebelumnya menghantarkan penelitian lebih dalam tentang PWB para penggemar K-Pop dewasa awal yang melakukan celebrity worship. Penelitian ini dilakukan pada penggemar K-pop dewasa awal di Indonesia, mengingat fenomena pemujaan terhadap selebriti K-Pop yang cukup jamak dilakukan oleh individu dewasa awal. Tujuan penelitian ini untuk menguji hipotesis ada tidaknya hubungan antara celebrity worship dan PWB penggemar K-Pop dewasa awal.

\section{Desain Penelitian}

\section{E T O D E}

Penelitian ini menggunakan metode penelitian kuantitatif dengan pendekatan eksplanatori. Berdasarkan dimensi waktunya, penelitian ini termasuk dalam penelitian cross-sectional. Model penelitian ini adalah studi korelasi, karena penelitian ini menguji apakah terdapat hubungan antara celebrity worship dan PWB pada penggemar K-Pop dewasa awal. Teknik pengumpulan data yang digunakan adalah dengan menggunakan metode survei dengan kuesioner secara daring.

\section{Partisipan}

Kriteria partisipan dalam penelitian ini adalah laki-laki atau perempuan, berusia 18-25 tahun, dan merupakan penggemar K-Pop yang memiliki selebriti favorit. Metode pengambilan sampel yang digunakan dalam penelitian ini adalah non-probability sampling dengan teknik purposive sampling untuk menjaring partisipan yang sesuai dengan kriteria. Sebelum mengisi kuisioner, partisipan diminta kesediaannya untuk berpartisipasi dalam penelitian dengan memberikan respon pada survei yang dibagikan.

Peneliti mengumpulkan sebanyak 1200 partisipan $\left(M_{\text {usia }}=21,06 ; S D_{\text {usia }}=1,83\right)$ di Indonesia untuk menguji hipotesis penelitian. Partisipan sebagian besar terdiri dari perempuan $(96,67 \%)$ dan sisanya adalah laki-laki (3,33\%). Berdasarkan frekuensi penggunaan waktu berinternet partisipan dalam satuan jam per hari, mayoritas partisipan menggunakan internet selama lebih dari 4 jam per hari sebanyak 941 orang $(78,42 \%)$. Partisipan lainnya menggunakan internet selama 3-4 jam per hari sebanyak 200 orang (16,67\%), 1-2 jam per hari sebanyak 53 orang $(4,41 \%)$, dan sisanya hanya menggunakan internet selama kurang dari 1 jam per hari sebanyak 6 orang $(0,50 \%)$.

\section{Pengukuran}

Penelitian ini menggunakan skala Psychological Wellbeing (PWB) berdasarkan teori C. Ryff yang telah diadaptasi ke dalam bahasa dan budaya Indonesia oleh Rachmayani dan Ramdhani (2014) untuk mengukur tingkat PWB. PWB terdiri dari 48 aitem dengan 5 pilihan jawaban berskala likert (1="sangat tidak sesuai", 5="sangat sesuai"). Validitas alat ukur berdasarkan nilai korelasi aitem berkisar antara 0,304 hingga 0,580, sedangkan untuk reliabilitas alat ukur berdasarkan nilai koefisien alpha adalah sebesar 0,912 .

Penelitian ini juga menggunakan alat ukur Celebrity Attitude Scale (CAS) yang dikembangkan oleh Maltby dan kawan-kawan (2004) dan sudah diterjemahkan ke dalam Bahasa Indonesia oleh Malahayati (2018). CAS terdiri dari 22 aitem untuk mengukur tingkat perilaku celebrity worship pada individu 
dengan 5 pilihan jawaban berskala likert ( $1=$ "sangat tidak sesuai", $5=$ "sangat sesuai"). Validitas alat ukur diperoleh dengan menggunakan teknik professional judgement, sedangkan untuk reliabilitas alat ukur berdasarkan nilai koefisien alpha adalah sebesar 0,905.

Cara perolehan skor setiap individu dari kedua alat ukur dilakukan dengan cara dijumlah. Skor partisipan selanjutnya digunakan sebagai data untuk melakukan penormaan dan uji asumsi parametrik. Berdasarkan hasil uji asumsi parametrik, data yang didapatkan memiliki distribusi yang tidak normal dan memiliki variansi yang tidak sama atau tidak homogen, sehingga analisis data selanjutnya dilakukan dengan menggunakan teknik analisis non-paramterik.

\section{Analisis Data}

Analisis penormaan kategorisasi data terbagi menjadi tiga kategori (rendah, sedang, tinggi) yang diperoleh dengan menggunakan acuan hipotetik dari masing-masing alat ukur. Analisis data untuk menguji hipotesis yang dilakukan adalah uji korelasi dengan menggunakan teknik analisis tes nonparametrik Spearman's Rank untuk mengetahui hubungan antara dua variabel penelitian. Peneliti juga melakukan analisis uji beda menggunakan teknik non-parametrik Kruskal-Wallis Test untuk mengetahui perbedaan hasil dari kedua variabel berdasarkan jenis kelamin dan waktu berinternet. Seluruh proses analisis data dilakukan dengan menggunakan bantuan perangkat lunak IBM SPSS Statistics Version 22 for Windows dan Microsoft Excel Version 365.

\section{HAS IL PENELITIAN}

Pertama-tama, penulis melakukan analisis deskriptif dari data penelitian. Pada variabel celebrity worship diperoleh nilai terendah sebesar 22, nilai tertinggi sebesar 106, nilai rata-rata sebesar 72,04, dan standar deviasi sebesar 12,59. Selanjutnya, pada variabel PWB diperoleh nilai terendah sebesar 130, nilai tertinggi sebesar 209, nilai rata-rata sebesar 163,56, dan standar deviasi sebesar 13,23.

Penulis juga melakukan penormaan data berdasarkan acuan hipotetik dari alat ukur untuk mengetahui posisi relatif partisipan secara umum sebagai kelompok. Pada variabel celebrity worship, sebanyak 295 orang berada pada tingkat yang tinggi $(24,60 \%), 844$ orang berada pada tingkat yang sedang $(70,30 \%)$, dan 62 orang berada pada tingkat yang rendah (5,10\%). Selanjutnya pada variabel PWB, sebanyak 208 orang berada pada tingkat yang tinggi (17,30\%), 992 orang berada pada tingkat yang rendah (82,70\%), dan tidak ada partisipan yang berada pada tingkat PWB rendah. Berdasarkan hasil uji korelasi, diketahui bahwa celebrity worship berkorelasi positif dengan PWB secara signifikan dan cenderung berkekuatan cukup $(r(1200)=0,34 ; p=0,00)$.

Terakhir, penulis melakukan analisis Kruskal-Wallis Test untuk menguji ada tidaknya perbedaan ratarata nilai celebrity worship dan PWB berdasarkan jenis kelamin dan waktu berinternet partisipan. Berdasarkan hasil uji beda pada variabel kelompok jenis kelamin, ditemukan bahwa terdapat pengaruh bermakna yang memberikan perbedaan signifikan pada nilai variabel celebrity worship $(p=0,01)$, tapi tidak pada nilai variabel PWB $(p=0,63)$. Selanjutnya, pada variabel kelompok waktu berinternet ditemukan bahwa terdapat pengaruh bermakna yang memberikan perbedaan signifikan pada nilai variabel celebrity worship $(p=0,04)$, yang juga ditemukan pula pada nilai variabel $\operatorname{PWB}(p=0,01)$. 


\section{I S K U S I}

Penelitian ini bertujuan untuk mengetahui hubungan antara celebrity worship dan PWB penggemar Kpop dewasa awal. Hasil analisis penelitian yang menguji korelasi antara celebrity worship dan PWB menunjukkan adanya hubungan dengan kekuatan cukup yang signifikan dari kedua variabel tersebut. Di samping itu, arah hubungan yang dihasilkan antara variabel celebrity worship dan PWB adalah positif, hal tersebut menunjukkan semakin tinggi tingkat celebrity worship maka akan diikuti oleh naiknya tingkat PWB pula dan begitu sebaliknya. Hasil penelitian ini bertolakbelakang dari temuan Maltby dan kawan-kawan (2001) yang menjelaskan bahwa individu yang melakukan pemujaan terhadap selebriti atau celebrity worship mendemonstrasikan beberapa aspek patologis dan memiliki fungsi psikologis serta wellbeing yang buruk. Maltby dan kawan-kawan (2001) menjelaskan adanya kemungkinan suatu interaksi budaya yang kompleks antara individu dengan perilaku celebrity worship yang didasari pada kemampuan untuk melakukan kegiatan apresiasinya serta media yang digunakan. Mekanisme ini diestimasi lebih dinamis dari apa yang terlihat dalam analisis korelasi penelitian. Dalam hal ini, faktor demografis juga disebutkan menjadi salah satu faktor yang mempengaruhi celebrity worship (Brooks, 2018). Sebagai contoh, Jung dan Hwang (2016, dalam Brooks, 2018) menemukan bahwa partisipan dari Amerika Serikat menunjukkan perilaku celebrity worship yang lebih parah dibandingkan Korea Selatan.

Mayoritas partisipan dalam penelitian ini berada pada tingkat celebrity worship dan PWB pada tingkatan sedang. Selain itu, yang menariknya dalam penelitian ini adalah tidak adanya partisipan yang ditemukan berada di tingkat PWB rendah. Temuan ini mendukung pernyataan Maltby dan kawan-kawan (2001) lainnya yang menyatakan bahwa sebetulnya perilaku celebrity worship juga secara potensial dapat bermanfaat bagi seorang individu. Maltby dan kawan-kawan (2001) menjelaskan bahwa dalam melakukan perilaku celebrity worship dapat memberikan kesempatan bagi individu untuk berpartisipasi dalam jaringan sosial sebagai penggemar dan perilaku tersebut pada akhirnya dapat mempromosikan hubungan sosial yang produktif serta dapat menyediakan penyangga psikologis untuk menghadapai stresor sehari-hari.

Maltby dan Day (2017 dalam Brooks, 2018) menjelaskan bahwa dimensi entertainment-social dari celebrity worship berhubungan dengan afek positif. Aspek ini berhubungan positif dengan kepuasan hidup (Chia \&Poo, 2009, dalam Brooks, 2018). Sejalan dengan ini, Nawardi dan Basaria (2020) juga menemukan bahwa kualitas hidup individu yang melakukan perilaku celebrity worship dari segi PWB dilaporkan baik. Lebih lanjut, Huang dan kawan-kawan (2015) menjelaskan bahwa kelompok penggemar yang mendapatkan penerimaan dan penghargaan terkait perilaku celebrity worshipnya dilaporkan memiliki tingkat kepercayaan dan kepuasan hidup yang tinggi. Pada prinsipnya, celebrity worship tidak akan menjadi masalah serius jika dilakukan selama tidak berlebihan secara obsesif, sedangkan untuk individu pada tingkatan celebrity worship yang lebih tinggi dengan tingkat absorption atau penyerapan yang lebih tinggi pula mungkin memiliki konsekuensi dan hubungan lebih besar terhadap kesehatan mental (Maltby dkk., 2004).

Penelitian ini juga menemukan bahwa terdapat perbedaan yang signifikan pada celebrity worship berdasarkan waktu penggunaan internet, dimana nilai rata-rata pada celebrity worship ditemukan lebih tinggi pada responden dengan penggunaan internet dalam waktu yang lebih lama. Perilaku celebrity worship terhadap selebriti K-Pop sebagian besar dilakukan melalui internet (Chang \& Park, 2012 dalam Necula, 2017). Perilaku celebrity worship merupakan bentuk dari interaksi parasosial yang merupakan fenomena abnormal dimana seseorang berasumsi bahwa identitas utuh dirinya menjadi terobsesi secara virtual dengan satu atau lebih selebriti (Maltby dkk., 2003). Seiring waktu, individu mengembangkan hubungan intim parasosial yang mencerminkan interaksi sosial kehidupan nyata yang diintensifkan saat individu mendapatkan informasi mengenai kehidupan pribadi selebriti kesukaannya melalui media virtual (Rasmussen, 2018).

Buletin Riset Psikologi dan Kesehatan Mental (BRPKM) 2021, Vol. 1(1), 137-148 
Menurut Schmid dan Klimmt (2011 dalam Rasmussen, 2018), interaksi parasosial merupakan respon psikologis yang langsung pada saat individu terpapar oleh media yang memberikan mereka informasi terkait selebriti dan paparan tersebut dapat mengintensifkan hingga mengubah interaksi parasosial individu menjadi hubungan parasosial (Rasmussen, 2018). Beberapa penelitian juga menyatakan bahwa teknologi komunikasi internet dapat mengubah interaksi parasosial menjadi representasi interaksi sosial yang lebih akurat (Ballantine \& Martin, 2005; Kassing \& Sanderson, 2009 dalam Rasmussen, 2018). Interaksi parasosial dapat diperkuat dengan kemampuan individu untuk memposting komentar atau mengirim email ke persona selebriti yang mereka sukai, dan hal ini sedikit banyak dapat menstimulasi interaksi sosial yang lebih realistis, terlepas dari apakah pesan tersebut diterima atau tidak (Rasmussen, 2018). Thorson dan Rodgers (2006, dalam Rasmussen, 2018) juga menemukan bahwa interaksi parasosial dipengaruhi oleh persepsi individu tentang interaksi interpersonal mereka melalui hubungan yang dimediasi oleh internet.

Penelitian ini juga menemukan bahwa terdapat perbedaan yang signifikan pada PWB berdasarkan waktu penggunaan internet. Secara rata-rata, tingkat PWB paling tinggi ditemukan pada responden dengan penggunaan internet dalam waktu kurang dari 1 jam sehari, dan paling rendah pada responden dengan penggunaan internet selama 34 jam sehari. Di sisi lain, responden dengan penggunaan internet selama 1-2 jam sehari dan lebih dari 4 jam sehari memiliki tingkat rata-rata diantaranya. Penggunaan internet telah menjadi bagian integral dari kehidupan kita sehari-hari, dan hal ini mengakibatkan beberapa aspek penggunaan yang bermasalah (misalnya, penggunaan Internet yang berkepanjangan) (Demetrovics \& Király, 2016; Yellowlees \& Marks, 2007 dalam Zsila dkk., 2018). Huang (2010) juga menjelaskan bahwa penggunaan internet memiliki konsekuensi kecil namun negatif bagi kesejahteraan psikologis, sehingga penting untuk memahami metodologi terbaik untuk memeriksa penggunaan internet.

Sampai saat ini penelitian-penelitian sebelumnya terkait perilaku celebrity worship lebih berfokus terdapat pembuktian terhadap hubungannya dengan aspek negatif seperti gejala dan gangguan mental yang digambarkan sebagai refleksi kondisi kesehatan mental yang buruk, self-esteem yang rendah, kesepian, dan ketidakmampuan dalam menghadapi situasi stres dengan perilaku celebrity worship. Kondisi PWB memang disebutkan menjadi salah satu faktor penyebab dari perilaku celebrity worship (Brooks, 2018) dan konsep kesehatan mental terkait erat dengan kondisi PWB (Fava, 2012). Namun, Price dan kawan-kawan (2014) menegaskan bahwa seharusnya kita tidak perlu mengharapkan adanya hubungan yang sangat kuat antara celebrity worship dengan kondisi masalah kesehatan mental dimana tentu saja memungkinkan adanya peran variabel lain yang lebih kompleks terhadap keduanya seperti pengalaman pribadi. Penelitian-penelitian sebelumnya yang lebih banyak menitik beratkan kepada hubungannya dengan status klinis dan gangguan mental justru dapat mengakibatkan stigmatisasi terhadap orang dengan riwayat penyakit mental akibat penggambaran perilaku terhadap selebriti sebagai konsumen kesehatan mental yang negatif (Price dkk., 2014).

Temuan penelitian ini menjadi sebuah diskusi menarik dimana penelitian-penelitian sebelumnya terkait celebrity worship yang hanya berfokus kepada aspek negatif khususnya afek negatif menemukan keterkaitan yang positif antara keduanya. Namun, pada penelitian kali ini yang lebih berfokus pada afek positif juga menemukan keterkaitan yang positif. Dalam hal ini, menjadi sebuah penjelasan baru apakah afek positif dan negatif merupakan dua kutub yang berbeda pada kontinum yang sama atau sebaliknya terdapat dua dimensi berbeda yang berdiri sendiri-sendiri (Vázquez dkk., 2009). Vázquez dan kawankawan (2009) menjelaskan, jika keduanya berada pada kontinum yang sama maka keberadaan dari afek positif akan mengindikasikan ketidakadaan dari afek negatif. Hal tersebut secara lebih jauh menjadikan penelitian terhadap dampak menguntungkan dari emosi positif menjadi kurang masuk akal karena seharusnya jika dengan begitu saja maka sudah cukup untuk mempertimbangkan penelitian yang

Buletin Riset Psikologi dan Kesehatan Mental (BRPKM) 2021, Vol. 1(1), 137-148 
secara sistematis berhubungan dengan keberadaan dari emosi negatif dengan kecenderungan gangguan tertentu (Booth-Kewley \& Friedman, 1987; Herbert \& Cohen, 1993 dalam Vázquez dkk., 2009). Namun, jika afek positif dan afek negatif merupakan hal yang kontras dan secara relatif merupakan dimensi independen (Bradburn, 1969 dalam Vázquez dkk., 2009) sebagaimana yang juga telah didemonstrasikan oleh beberapa temuan sebelumnya (Vázquez, 2000a dalam Vázquez dkk., 2009), maka maka akan menjadi tepat dan menarik untuk mempelajari manfaat spesifiknya bahwa kehadiran pengaruh positif dapat berkontribusi pada kondisi kesehatan.

\section{S I M P U L A N}

Hasil penelitian yang telah dilakukan menunjukkan bahwa terdapat hubungan antara celebrity worship dengan psychological wellbeing pada penggemar K-Pop dewasa awal. Korelasi antara keduanya berkekuatan cukup dengan arah positif. Artinya, jika celebrity worship meningkat maka psychological wellbeing juga akan meningkat dan begitu pula sebaliknya.

Penelitian ini dapat menjadi referensi bagi penelitian berikutnya untuk mengkaji fenomena perilaku celebrity worship dengan pendekatan psikologi positif mengingat penelitian-penelitian terdahulu lebih berfokus pada hubungannya dengan afek negatif. Penelitian ini juga dapat menjadi salah satu referensi reflektif dan evaluatif bagi para penggemar K-Pop yang disarankan untuk terus saling mendukung satu sama lain dan tidak berlebihan dalam melakukan celebrity worship. Disamping itu, masyarakat diharapkan dapat memberikan lingkungan yang suportif terhadap penggemar K-Pop serta tidak langsung memberikan stigma yang negatif karena adanya aspek positif dari perilaku celebrity worship. Namun, dukung suportif yang diberikan terhadap demonstrasi perilaku celebrity worship ini juga tetap harus diimbangi dengan pengawasan dan saling mengingatkan agar dampak negatif akibat perilaku yang berlebihan dapat dicegah.

Salah satu kekurangan penelitian ini adalah pemilihan alat ukur Celebrity Attitude Scale yang tidak mengkategorikan skor dalam tingkat Entertainment social, Intense-Personal, atau Borderline Pathological (Magpantay dkk., 2013). Penelitian selanjutnya disarankan untuk meneliti hubungan antara celebrity worsip dan psychological wellbeing berdasarkan tingkatan tersebut sehingga perbedaan antar tingkatan dapat dikonfirmasi.

\section{U C A P A N T ERIMAKASIH}

Terima kasih kepada seluruh partisipan yang telah bersedia untuk berkontribusi terhadap penelitian ini, semoga hasil dari penelitian ini dapat menjadi pertanggung jawaban terhadap partisipan yang telah membantu. Terima kasih pula kepada Universitas Airlangga yang telah memfasilitasi pelaksanaan penelitian ini, semoga penelitian ini dapat menjadi salah satu sumbangan keilmuan yang baik pada bidang psikologi.

\section{DEKLARASI POTENSI TERJADINYAKONFLIK KEPENTINGAN}

Mauliddita Salsabila Azzahra dan Atika Dian Ariana tidak bekerja, menjadi konsultan, memiliki saham, atau menerima dana dari perusahaan atau organisasi manapun yang mungkin akan mengambil untung dari diterbitkannya naskah ini. 


\section{PUSTAKA ACUAN}

Anwar, D. C. R. (2018). Mahasiswa dan K-POP. Jurnal Ilmu Komunikasi, 1(1). https://doi.org/10.33005/jkom.v1i1.12

Brooks, S. K. (2018). FANatics: Systematic literature review of factors associated with celebrity worship, and suggested directions for future research. Current Psychology. https://doi.org/10.1007/s12144-018-9978-4

Cahyani, D., \& Purnamasari, Y. (2019). Celebrity Worship on Early Adult K-Pop Fangirling. 304(Acpch 2018), 167-170. https://doi.org/10.2991/acpch-18.2019.41

Çikrikci, Ö. (2016). The effect of internet use on well-being: Meta-analysis. Computers in Human Behavior, 65, 560-566. https://doi.org/10.1016/j.chb.2016.09.021

Fava, G. A. (2012). The clinical role of psychological well-being. World Psychiatry, 11(2), 102-103. https://doi.org/10.1016/j.wpsyc.2012.05.018

Huang, C. (2010). Internet use and Psychological Well-Being: A Meta-Analysis. Cyberpsychology, Behavior, and Social Networking, 13(3), 241-249. https://doi.org/10.1089/cyber.2009.0217

Huang, Y. A., Lin, C., Su, H. J., \& Tung, M. L. (2015). I worship, so I download? Idol worship, music purchase and piracy by young consumers in Taiwan. Asia Pacific Journal of Marketing and Logistics, 27(1), 99-126. https://doi.org/10.1108/APJML-03-2014-0050

Kim, Y. (2020). Celebrating 10 years of \#KpopTwitter. Twitter Blog. https://blog.twitter.com/en_us/topics/insights/2020/Celebrating10yearsofKpopTwitter.html

Magpantay, J. A. G., Tolentino, R. M. N., Varona, A. A., Vega, C. B. C., \& Zapanta, J. Y. R. (2013). Celebrity Attitude and Body-Image of Selected College Students of The University Belt Consortium: A Correlational Study. University of Santo Tomas, Philipina.

Malahayati, S. (2018). Hubungan Antara kesepian dan celebrity worship pada Penggemar K-pop dewasa awal. Universitas Airlangga.

Maltby, J., Day, L., McCutcheon, L. E., Gillett, R., Houran, J., \& Ashe, D. D. (2004). Personality and coping: A context for examining celebrity worship and mental health. British Journal of Psychology, 95(4), 411-428. https://doi.org/10.1348/0007126042369794

Maltby, J., Day, L., McCutcheon, L. E., Houran, J., \& Ashe, D. (2006). Extreme celebrity worship, fantasy proneness and dissociation: Developing the measurement and understanding of celebrity worship within a clinical personality context. Personality and Individual Differences, 40(2), 273-283. https://doi.org/10.1016/J.PAID.2005.07.004

Maltby, J., Houran, J., \& McCutcheon, L. E. (2003). A clinical interpretation of attitudes and behaviors associated with celebrity worship. Journal of Nervous and Mental Disease, 191(1), 25-29. https://doi.org/10.1097/00005053-200301000-00005

Maltby, J., McCutcheon, L. E., Ashe, D. D., \& Houran, J. (2001). The Self-Reported Psychological Well-Being of Celebrity Worshippers. North American Journal of Psychology, 3(3), 441. https://doi.org/Article

Mandas, A. L., Suroso, \& Sarwindah, D. (2018). Hubungan Antara Konsep Diri Dengan Celebrity Worship Pada Remaja Pecinta Korea Di Manado Ditinjau Dari Jenis Kelamin. Psikovidya, 22(2), 164-189.

Mccutcheon, L. E., Lange, R., \& Houran, J. (2002). Conceptualization and measurement of celebrity worship Illinois State Board of Education and Southern Illinois University School of Medicine ,. 67-87. 
Nawardi, L., \& Basaria, D. (2020). Quality of Life of Early Adults that Become Celebrity Worshipers. 439(Ticash 2019), 695-700.

Necula, A. E. (2017). The Hallyu Influence . K-POP on Foreign Lands. 1, 295-301.

Price, J. L., Lowinger, R. J., Jenkins, W., \& Mccutcheon, L. E. (2014). The Stigmatization of People with a History of Mental Illness by Those Who Admire Celebrities. 16(2), 253-260.

Puspitasari, W., \& Hermawan, Y. (2013). Gaya Hidup Penggemar K-Pop (Budaya Korea) Dalam Mengekspresikan Kehidupannya Studi Kasus K-Pop Lovers Di Surakarta. Sosialitas: Jurnal Ilmiah Pendidikan Sosiologi-Antropologi.

Rachmayani, D., \& Ramdhani, N. (2014). Adaptasi Bahasa dan Budaya Skala Psychological Well-Being Fakultas Psikologi Universitas Muhammadiyah Surakarta - 2014. Adaptasi Bahasa Dan Budaya Skala Psychological Well-Being, May 2014, 253-254.

Rasmussen, L. (2018). Parasocial Interaction in the Digital Age: An Examination of Relationship Building and the Effectiveness of YouTube Celebrities. The Journal of Social Media in Society Spring, 7(1), 280-294. www.youtube.com

Rosida, A. (2019). Hubungan Self-Esteem dan Kesepian dengan Celebrity Worship pada Wanita Dewasa Awal Penggemar K-Pop. Universitas Airlangga.

Ryff, C. D. (2013). Psychological well-being revisited: Advances in the science and practice of $\begin{array}{llll}\text { eudaimonia. Psychotherapy and } & \text { Psychosomatics, }\end{array}$ https://doi.org/10.1159/000353263

Santrock, J. W. (2013). Life-Span Development (14th ed.). McGraw Hill.

Shofa, M. (2017). Gambaran Psikologis Celebrity Worship pada Dewasa Awal (Studi Kasus Mahasiswa Penggemar Korean Pop). Universitas Islam Negeri Maulana Malik Ibrahim Malang.

Vázquez, C., Hervás, G., Rahona, J. J., \& Gómez, D. (2009). Psychological well-being and health. Contributions of positive psychology. Annuary of Clinical and Health Psychology, 5, 15-27. https://doi.org/10.1109/ITW.2008.4578636

Winefield, H. R., Gill, T. K., Taylor, A. W., \& Pilkington, R. M. (2012). Psychological well-being and psychological distress: is it necessary to measure both? Psychology of Well-Being: Theory, Research and Practice, 2(1), 3. https://doi.org/10.1186/2211-1522-2-3

Zsila, Á., McCutcheon, L. E., \& Demetrovics, Z. (2018). The association of celebrity worship with problematic Internet use, maladaptive daydreaming, and desire for fame. Journal of Behavioral Addictions, 7(3), 654-664. https://doi.org/10.1556/2006.7.2018.76 